\title{
Si Uptake and Transport in Higher Plants
}

\author{
Harmanjit Kaur* and Maria Greger* \\ Department of Ecology, Environment and Plant Sciences, Stockholm University, Sweden
}

Submission: April 17, 2019; Published: April 26, 2019

*Corresponding author: Harmanjit Kaur and Maria Greger, Department of Ecology, Environment and Plant Sciences, Stockholm University, 10691 Stockholm, Sweden

Keywords: Silicon transporters; Silicic acid; Metabolic inhibitors

\section{Mini Review}

Silicon ( $\mathrm{Si}$ ) is the second most abundant element in the earth crust and is valued for its innumerable beneficial properties required for the growth and development of the plant specially under stressed environmental conditions [1]. Despite of this fact, it is not considered as an essential element for majority of the plants; as it was believed that most plants can complete their normal life cycle without supplementation of silicon to the soil [2]. However, more recently it has been observed that continuous application of NPK and other chemical fertilizers have depleted the normal Si availability in the soil. The beneficial effects such as in protecting and stabilizing the plant structure, salt and drought tolerance, diseases resistance, yield and development of the plant imposed by the element have made plant physiologist to realize the importance of adding additional silicon fertilizers to the soil $[3,4]$. Now a days, Si fertilizers are regularly added to rice and sugarcane crops to enhance crop yields [2]. However, the availability of Si towards the plant is another interesting point to study as the uptake and translocation mechanism is greatly dependent on the uptake ability of the plant root system [5].

Silica is mainly taken up by the plants as silicic acid [ $\mathrm{Si}$ $\left.(\mathrm{OH})_{4}\right]$, an uncharged monomeric molecule [6]. Following its uptake by the roots, it is further transported to shoots via xylem wherein; it gets chemically mineralized to form silica gel $\mathrm{SiO}_{2}$. $\mathrm{nH}_{2} \mathrm{O}$ ) due to higher transpiration rates [7]. This mineralized silica aggregates i.e. phytoliths which resemble Si nanoparticles (SiNP) provides protection and strength to the plant structure [8]. This further bring in resurgence of interest in studying the underlying mechanism of uptake and translocation of silicon into the plants. Different parameters play different parts in the uptake and accumulation process. Some of these are highlighted in this review.

\section{Role of Si transporters in uptake process}

Based on diverse absorption ability of the roots, different plants have different $\mathrm{Si}$ accumulation levels and are categorized as high, low and intermediate accumulators. For instance, higher plants of family Gramineae and Cyperacea show high $\mathrm{Si}$ accumulation and plants belonging to family Cucurbitales, Urticales, and Commelinaceae show intermediate Si accumulation, while many other plant families like Asteraceae and Fabaceae shows low Si accumulation [8,9]. The difference in the Si uptake system is attributed to the participation of different parts of the root structure. A root system consists of primary roots, lateral roots and root hairs. Different experiments were conducted to study the effects of different root parts in Si uptake process. Ma [10] conducted experiment on two different rice mutants one defective in the formation of root hairs (RH2) and the other in the formation of lateral roots (RM109). From the experiments, it was concluded that plants that lacked lateral roots (RM109) resulted in reduced Si uptake while in the RH2 type plants there was no significant effect on the uptake process. Thus, it was very clear that lateral roots are the major components of the root systems wherein a specific transport system is present which aids in the Si uptake [11]. Therefore, based upon physiological studies; it was revealed that a specific transport system consisting of $\mathrm{Si}$ transporters exists across the membranes which help mediates the entire uptake process $[6,12]$. This transport system consisted of various channel proteins of NIP major protein family and aquaporins subfamily [13]. An efficient transport system helps plant to benefit from the useful effects of Si.

The very first report in higher plants was from rice wherein two different genes Lsi1 and Lsi2 were identified [2]. The influx transporter Lsi1, absorbs Si from the soil solution and transports across the exodermis while Lsi2, the efflux transporter helps transporting Si from endodermal cells into the xylem parenchyma, surrounding the xylem translocation vessel. There from, either Lsi 6 in the case of Si accumulators or a passive transport in non-accumulators will facilitate the transport into the xylem vessel and thereafter the Si translocation to the shoots [14]. Structural localization of different Si transporters help facilitates the influx and efflux across the different plant parts. 
Homologs of rice transporters Lsi1 and Lsi2 have further been identified and characterized in number of other plants including barley (Hordeum vulgare), maize (Zea mays), pumpkin (Cucurbita moschata), horsetail (Equisetum arvense), Cucumber (Cucumis sativus), Wheat (Triticum aestivum), Soy bean (Glycine max) and Potato (Solanum tuberosum) (Table 1).

Table 1: Presence of influx and efflux transporters in different plants.

\begin{tabular}{|c|c|c|c|}
\hline Plants & Si Influx Transporters & Si Efflux Transporters & Reference \\
\hline Wheat & TaLsi1 & --- & Montpetit [15] \\
\hline Barley & HvLsi1 & $H v L s i 2$ & Chiba [16] \\
\hline Maize & ZmLsi1;ZmLsi6 & Zmlsi2 & Mitani [17] \\
\hline Pumpkin & CmLsi1(B+);Cmlsi1(B-) & $-\ldots-$ Mitani [4] \\
\hline Cucumber & CsLsi1 & CsLsi2 & Sun [18,19] \\
\hline Potato & StLsi1 & ---- & Vulavala [20] \\
\hline Soybean & GmNIP2-1 & GmNIP2-2 & Deshmukh [21] \\
\hline Horsetail & EaNIP3;1; EaNIP3;4 & EaLsi2-1; EaLsi2-2 & Vivancos [22], Gregoire [23] \\
\hline
\end{tabular}

\section{Role of metabolic inhibitors on Si uptake}

It has been observed that plants such as rice, wheat, barley, ryegrass and some belonging to cyperaceous family have an active intake of Si while some dicots such as melon, strawberry and soybean take up Si passively $[10,24,25]$. Plants having active uptake process have much higher intake of $\mathrm{Si}$, which is not affected by the transpiration but is influenced by the presence of various inhibitors such as $\mathrm{NaCN}, \mathrm{NaF}, \mathrm{H}_{2} \mathrm{~S}, 2$,4-DNP (2,4-dinitrophenol), iodo-acetate, 2, 4-D (2,4-dichlorophenoxyacetic acid), $\mathrm{HgCl}_{2}$ $[26,27]$. The very first report to study the effect of metabolic inhibitors was by Okuda and Takahashi [24] in rice roots and shoots. The experiments clearly showed that excised roots were strongly inhibited by metabolic inhibitors such as NaF and 2,4D. On the other hand, shoots were not affected thereby showing that in shoots passive transport of Si occurs which is along the transpiration stream while in roots active process using ATP is involved. Commonly studied metabolic inhibitors influencing $\mathrm{Si}$ uptake studies are listed in Table 2.

Table 2: Commonly used metabolic inhibitors.

\begin{tabular}{|c|}
\hline Metabolic Inhibitors \\
\hline 2, 4-D (2,4-dichlorophenoxyacetic acid) \\
\hline 2,4-dinitrophenol $(2,4-\mathrm{DNP})$ \\
\hline Sodium phosphate $\left(\mathrm{Na}_{3} \mathrm{PO}_{4}\right)$ \\
\hline Mercuric chloride $\left(\mathrm{HgCl}_{2}\right)$ \\
\hline Malonic acid $\left(\mathrm{C}_{3} \mathrm{H}_{4} \mathrm{O}_{4}\right)$ \\
\hline $\mathrm{NaCN}, \mathrm{NaF}$ \\
\hline
\end{tabular}

Liang [28] studied inhibitory effect of three metabolic inhibitors (NaF, NaCN and 2,4-DNP) on Si uptake in four different plant species and found that the effects were much enhanced in Oryza sativa and Zea mays as compared to Helianthus annuus and Benincase hispida. In another study by Zhang [29] effect of four different inhibitors including $\mathrm{HgCl}_{2}$, 2,4-dinitrophenol (2,4-DNP), malonic acid $\left(\mathrm{C}_{3} \mathrm{H}_{4} \mathrm{O}_{4}\right)$, and sodium phosphate $\left(\mathrm{Na}_{3} \mathrm{PO}_{4}\right)$ were studied in the Si uptake in association with their effects on ATPase activity and ATP concentration in rice.

\section{Other factors affecting Si uptake}

The other factors contributing towards the uptake of $\mathrm{Si}$ includes transpiration, nutrient salts, temperature, and light. In different sets of experiments conducted on rice to study the transpiration rates it was observed that $\mathrm{Si}$ concentration is higher in aerial parts where the transpiration rates are higher [30]. Similarly, light also stimulated the uptake effect of $\mathrm{Si}$ as prolonged exposure of rice plants to light enhanced the Si content as compared to short exposures [30]. In Cucumber, it was found that low temperature exposure strongly inhibited the Si uptake process [31]. Deficiency of nitrogen and phosphorous in rice plants increased silicon uptake suggesting that different nutrient salts have varied influences on the uptake process [32]. Similar results were obtained in another experiment on Oryza sativa L. cv. Akebono, where uptake of $\mathrm{Si}$ in shoots was reduced when the concentration of phosphorous was increased [33]. Effect of temperature on Si uptake was studied in four different plants including Oryza sativa, Zea mays, Helianthus annuus and Benincase hispida. It was observed that low temperatures significantly suppressed the Si uptake levels independent of higher external Si concentrations [28].

Even though $\mathrm{Si}$ exerts numerous useful effects on the plant's growth and development; most plants are deprived of these benefits from $\mathrm{Si}$ due to the lack of an efficient transport mechanism. Therefore, it is of utmost importance to study the various parameters influencing the uptake and translocation process to get a better insight of the transport system of silica. In the present review, we tried to pin point some of the most important factors influencing silicon uptake in higher plants which could become the blocks for future research experiments.

\section{References}

1. Imtiaz M, Rizwan MS, Mushtaq MA, Ashraf M, Shahzad SM, et al (2016) Silicon occurrence, uptake, transport and mechanisms of heavy metals, minerals and salinity enhanced tolerance in plants with future prospects: a review. J Environ Manag 183(Pt 3): 521-529.

2. Ma JF, Yamaji N (2006) Si uptake and accumulation in higher plants. Trends Plant Sci 11(8): 392-397. 
3. Yamaji N, Mitani N, Ma JF (2008) A transporter regulating Si distribution in rice shoots. Plant Cell 20(5): 1381-1389.

4. Mitani N, Yamaji N, Ago Y, Iwasaki K, Ma JF (2011) Isolation and functional characterization of an influx Si transporter in two pumpkin cultivars contrasting in Si accumulation. Plant J 66(2): 231-240.

5. Mitani N Ma JF (2005) Uptake system of Si in different plant species. J Exp Bot 56(414): 1255-1261.

6. Ma JF, Yamaji N, Mitani-Ueno N (2011) Transport of Si from roots to panicles in plants. Proc Jpn Acad Ser B Phys Biol Sci 87(7): 377-385.

7. Bockhaven JV, De Vleesschauwer D, Höfte M (2013) Towards establishing broad-spectrum disease resistance in plants: silicon leads the way. J Exp Bot 64(5): 1281-1293.

8. Hodson MJ, White PJ, Mead A, Broadley MR (2005) Phylogenetic variation in the Si composition of plants. Ann Bot 96(6): 1027-1046.

9. Kaur H, Greger M (2019) A Review on Si Uptake and Transport System. Plants (Basel) 8(4): e81.

10. Ma JF, Miyakeb Y, Takahashi E (2001) Si as a Beneficial Element for Crop Plants. In: Datnoff LE, Snyder GH, Korndörfer GH (Eds.), Si in Agriculture. Elsevier: Amsterdam, The Netherlands 8: 17-39.

11. Reed RC, Brady SR, Muday GK (1998) Inhibition of auxin movement from the shoot into the root inhibits lateral root development in Arabidopsis. Plant Physiol 118(4): 1369-1378.

12. Ma JF, Yamaji N, Mitani N, Tamai K, Konishi S, et al. (2007) An efflux transporter of Si in rice. Nature 448(7150): 209-212.

13. Gomes D, Agasse A, Thiebaud P, Delrot S, Geros H, et al. (2009) Aquaporins are multifunctional water and solute transporters highly divergent in living organisms. Biochim Biophys Acta 1788(6): 12131228.

14. Ma JF, Yamaji N (2015) A cooperative system of silicon transport in plants. Trends in plant Science 20(7): 435-442.

15. Montpetit J, Vivancos J, Mitani-Ueno N, Yamaji N, Rémus-Borel W, et al. (2012) Cloning, functional characterization and heterologous expression of TaLsi1, a wheat Si transporter gene. Plant Mol Biol 79 35-46.

16. Chiba Y, Mitani N, Yamaji N, Ma JF (2009) HvLsi1 is a Si influx transporter in barley. Plant J 57(5): 810-818.

17. Mitani N, Yamaji N, Ma JF (2009) Identification of maize Si influx transporters. Plant Cell Physiol 50(1): 5-12.

18. Sun H, Guo J, Duan Y, Zhang T, Huo H, et al. (2017) Isolation and functional characterization of CsLsi1, a Si transporter gene in Cucumis sativus. Physiol Plant 159(2): 201-214.

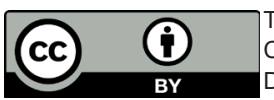

his work is licensed under Creative Commons Attribution 4.0 License DOI: 10.19080/IJESNR.2019.19.556001
19. Sun H, Duan Y, Qi X, Zhang L, Huo H, et al. (2018) Isolation and characterization of CsLsi2, a cucumber Si efflux transport gene Ann Bot 122(4): 641-648.

20. Vulavala VKR, Elbaum R, Yermiyahu U, Fogelman E, Kumar A, et al. (2016) Si fertilization of potato: Expression of putative transporters and tuber skin quality. Planta 243(1): 217-229.

21. Deshmukh RK, Vivabcos J, Guerin V, Sonah H, Labbe C, et al. (2013) Identification and functional characterization of $\mathrm{Si}$ transporters in soybean using comparative genomics of major intrinsic proteins in Arabidopsis and rice. Plant Mol Biol 83(4-5): 303-315.

22. Vivancos J, Deshmukh R, Gregoire C, Remus-Borel W, Belzile F, et al. (2016) Identification and characterization of Si efflux transporters in horsetail (Equisteum arvense). J Plant Physiol 200: 82-89.

23. Gregoire C, Remus-Borel W, Vivancos J, Labbe C, Belzile F, et al. (2012) Discovery of a multigene family of aquaporin Si transporters in the primitive plants Equisetum arvense. Plant J 72(2): 320-330.

24. Okuda A, Takahashi E (1962a) Studies on the physiological role of silicon in crop plant: VIII. Some examination on the specific behavior of low land rice in silicon uptake. J Soil Sci Manure Jpn 33: 217-221.

25. Jones LHP, Handreck KA (1967) Silica in soils, plants and animals. Adv Agron 19: 107-149.

26. Okuda A, Takahashi E (1962b) Studies on the physiological role of silicon in crop plant: IX. Effect of various metabolic inhibitors on the silicon uptake by rice plant. J Soil Sci Manure Japan 33: 453-455.

27. Mehrabanjoubani P, Abdolzadeh A, Sadeghipour Hamid, Aghdasi Mahnaz (2014) Impacts of silicon nutrition on growth and nutrient status of rice plants grown under varying zinc regimes. Theoretical and Experimental Plant Physiology 27(1): 19-29.

28. Liang Y, Hua H, Zhu YG, Zhang J, Cheng C, et al. (2006) Importance of plant species and external silicon concentration to active silicon uptake and transport. New Phytol 172(1): 63-72.

29. Zhang J, Liu H, Zhao QZ, Du, YX, Chang QX, et al. (2011) Effects of ATP production on silicon uptake by roots of rice seedlings Plant Biosystems 145(4): 866-872.

30. Ma JF, Takahashi E (2002) Soil, Fertilizer and plant Research in Japan. Elsevier. Netherlands.

31. Liang Y, Si J, Römheld V (2005) Si uptake and transport is an active process in Cucumis sativus. New Phytol 167(3): 797-804.

32. Takahashi E, Nishi T (1982) Effects of nutritional conditions on the silicon uptake by rice plants. Comparative studies on silica nutrition in plants (Parts 21). Japan J soil Sci Plant Nutr 53: 395-401.

33. Ma J, Takahashi E (1990) Effect of silicon on the growth and phosphorus uptake of rice. Plant and Soil 126(1): 115-119.

\section{Your next submission with Juniper Publishers will reach you the below assets}

- Quality Editorial service

- Swift Peer Review

- Reprints availability

- E-prints Service

- Manuscript Podcast for convenient understanding

- Global attainment for your research

- Manuscript accessibility in different formats

( Pdf, E-pub, Full Text, Audio)

- Unceasing customer service

Track the below URL for one-step submission https://juniperpublishers.com/online-submission.php 